PRELIMINARY PETROGRAPHIC AND GEOCHEMICAL CONSIDERATIONS ON THE PRECAMBRIAN MAF IC DYKES OF THE ILHEUS-OLIVENÇA AREA, BAHIA

\author{
M.A.F. Tanner de Oliveira! \\ G. Bellieni ${ }^{2}$ \\ P.Comin-Chiaramont $i^{3}$ \\ A.J.Melfi \\ E.M.Piccirillo \\ C. Moraes-Brito ${ }^{6}$
}

GEQLOGICAL SETTING

Anorogenic dykes occur over $18 \mathrm{~km}$ of the coast of the state of Bahia. They show NNW trends and are remarkably concentrated in the area between Ilhéus and Olivença where they constitute one of the best mafic dyke exposures of Brazil (Fig. 1). The dykes cut granulites of the "Atlantic domain" (BARBOSA, 1986) and are associated with tensional tectonics of EW, WNW and ENE trends. They are vertical to subvertical, $20 \mathrm{~cm}$ to $30 \mathrm{~m}$ wide (most often $3 \mathrm{~m}$ wide), and exhibit structural features that suggest flow during emplacement from east to west.

\title{
CLASSIFICATION AND PETROGRAPHY
}

Classification of the mafic rocks (Fig. 2) is in accordance with the De La ROCHE et al. (1980) parameters, $R_{1}$ and $R_{2}$, modified by BELLIENI et al. (1981), and adding the high and low titanium qualifiers $\left(\mathrm{HTi}_{\mathrm{T}} \mathrm{TiO}_{2}>2.0 \%\right)\left(\mathrm{LT} i=\mathrm{TiO}_{2}<2.0 \%\right)$. Thus, the mafic rocks were classified as tholeiitic basalts ( $H T i$ and $L T i$ ), transitional basalts ( $H T i-L T i$ ), andesi-basalts (HTi), lati-basalts (HTi) and hawaiites (HTi).

The studied mafic rocks are mesocratic (dark gray, generally), aphanitc to phaneritic (fine to medium grained), porphyritic or aphyric, and with ophitic to intergranular textures. The major mineralogical composition is determined by plagioclase and pyroxene, but pyroxene predominates in practically all of the classified types, except for the hawaites, in which plagioclase predominates. The plagioclase is labradorite. The

\footnotetext{
1'Instituto de Geociências, Universidade Federal da Bahia, Rua Caetano Moura 123, 40210 Salvador, BA, Brasil.

2Dipartimento di Mineralogia e Petrologia, Università di Padova, Corso Garibaldi 37, 35100 Padova, Italia.

3istituto di Mineralogía, Petrologia e Geochimica, Università di Palermo, Via Archiraffi, 90100 Palermo, Italía.

4Instituto Astronômíco e Geofísico, Universidade de Săo Paulo, Caixa Postal 30627, 01051 Săo Paulo, SP, Brasil.

5stituto di Mineralogia e Petrologia, Università di Trieste, Piazzale Europa 1, 34100 Trieste, Italia.
} 
anorthite proportion is lower for the lat1-basalts (53\%) than for the hawailtes (61\%). Augite is the most common pyroxene, but calcic augite and pigeonite have been recognized in the andesi-basalts and transitional basalts. Moreover, hypersthene is comnon in the transitional basalts as well as in the tholeiltes. Olivine is commom in the hawailes and is rare in the andesi-basalts and tholeiltes. Magnetite and subordinate ilmenite are oxides present within the rocks and as phenocrysts ( 0.1 to $0.7 \%$ in frequency); in the aphyric types the oxides vary between $5 \%$ and $24 \%$. Apatite and zircon are the accessory minerals. Primary hornblende has been found in the hawailtes and lati-basalts. Secondary minerals are uraninite, chlorite, biotite and saussurite.

\section{GEOCHEMISTRY}

Figure 3 shows the AFM diagram for the studied samples in which the observed trend is coherent with the tholeiitic field (in accordance wIth IRVINE \& BARAGAR, 1971), with Feenrichment for the HT1 types. A similar geochemical pattern is observed for the Itabuna-Itaju mafic dykes.

Figure 4 presents the REE distribution pattern normalized for chondritic values. The data plots are similar to the field for Columbia River continental basalts. In addition, the chemistry of LTi types resembles that for intraplate oceanic basalts (Hawaii types). The REE fractionation index (La/Nb) is approximately constant for the studied rocks $(H T 1=3.96$ and $L T i=3.38)$.

Figure 5 shows postulated chemical trends according to ANDERSON (1981). The sources of mid-oceanic ridge basalts and hotspots (principal layer of upper mantle enrichment) are delineated, the latter being associated with the generation of continental basalts (kimberlites, alkaline basalts, tholeiites). Fron this diagram it is clear that the continental crust is not the unique enriched source for continental basalts. In fact, in this diagram the studied basaltic dykes show a distribution which is consistent with continental tholeites generated by partial melting of enriched mantle.

\section{REFERENCES}

ANDERSON, D.L. (1981) Hotspots, basalts and the evolution of the mantle. Science, 213:82-89.

BARBOSA, J. (1986) Constitution on lithologique et metamorphic de la region granulitique du sud de Bahia, Brésil. París, 401p. (Thése du Doctorat - Université Plerre et Marie Curie).

BELLIENI, G.; COMIN-CHIARAMONTI, P.; MARQUES, L.S.; MELFI, A.J.; PICCIRILLO, E.M.; STOLFA, D. (1984) Low pressure evolution of basalt sills from boreholes in the Paraná plateau (Brazil): petrology and geochenical aspects bearing on their mantle origin. Neves Jahrbuch fur Mineralogie Abhandlungen, 150(3):273-306.

De La ROCHE, H.; LETERRIER, J.; GRANDCLAUD, P.; MARCHAL, M. (1980) A classification of volcanic and plutonic rocks using $R_{1}-R_{2}$ diagram and major element analyses. Its relationships with current nomenclature. Chenical Geology, 29:183-210.

IRVINE , T.N. \& BARAGAR, W.R.A. (1971) A guide to the chemical classification of the common volcanic rocks. Canadian Journal of Earth Sciences, 8:523-548. 
Bol.IG-USP, Sér.Cient., 20: 15-19, 1989.

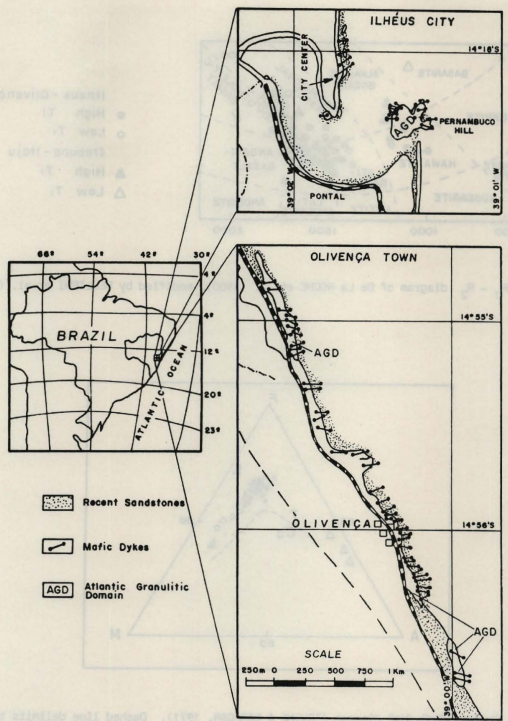

Figure 1 - Geologic setting of the Ilhéus-0livença area. 


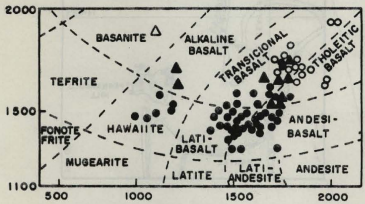

IInéus - olivenço

- High Ti

- Low Ti

Itabuna-itaju

- High $\mathrm{Ti}$

$\Delta$ Low Ti

Figure $2-R_{1}-R_{2}$ diagram of De La ROCHE et al. (1980), modified by BELLIENI et al. (1981).

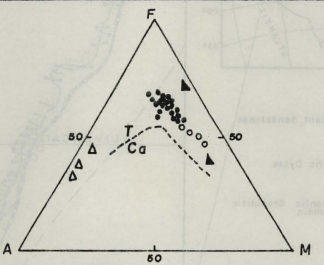

Figure $3-\mathrm{Na}_{2} \mathrm{O}-\mathrm{K}_{2} \mathrm{O} / \mathrm{FeO}_{\mathrm{t}} / \mathrm{MgO}$ diagram (IRVINE \& BARAGAR, 1971). Dashed line delimits the calcalkaline (Ca) and tholeitte $(\mathrm{T})$ fields. 
Bol.IG-USP, Sér.Cient., 20:15-19, 1989.

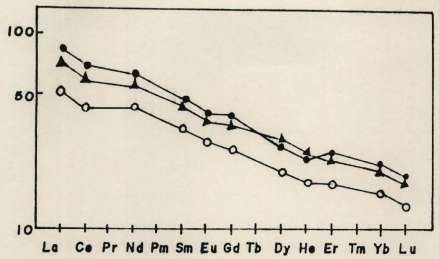

Figure 4 - REE distribution for the studied rocks. Values normalized for chondrites (symbols as in Fig. 1).

ILHÉUS - OLIVENCA

- High Ti

- Low Ti

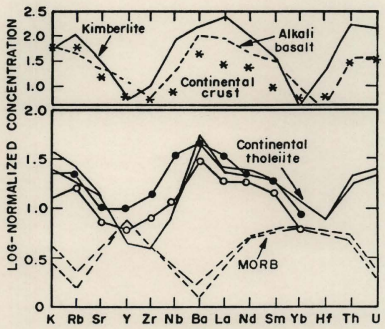

Figure 5 - Distribution of trace elements normalized for primordial mantle values (ANDERSON, 1981). For explanation, see text. 